\title{
Exchange Rate Variations and Agricultural Exports in Vietnam
}

\author{
Dinh Xuan Cuong ${ }^{1}$, Ph.D. \& Nguyen Quoc Toan ${ }^{2}$, Ph.D. \\ ${ }^{1}$ Vietnam National University, Hanoi, Vietnam \\ ${ }^{2}$ Central Economic Commission, PCV, Hanoi, Vietnam \\ Correspondence: Dinh Xuan Cuong, Vietnam National University, 144 Xuan Thuy Road, Cau Giay District, Hanoi, \\ Vietnam. \\ Received: March 16, 2016 \\ Accepted: April 4, 2016 \\ Online Published: April 15, 2016 \\ doi:10.5430/afr.v5n2p54 \\ URL: http://dx.doi.org/10.5430/afr.v5n2p54
}

This research is funded by Vietnam National University, Hanoi (VNU) under project number QG.16.54.

\begin{abstract}
This article studies the situation of exchange rate since the end of 2014 until now and gives analysis about the effects of exchange rate viariations on agricultural export market of Vietnam in this period. Specifically, we focuse on the adjustments of the State Bank of Vietnam as the US dollar's price fluctuates and yuan is devalued. Besides, we also analyse the consequences that agriculture is affected by unfavorable changes of the market.
\end{abstract}

Keywords: Exchange rate, Agricutural exports, Vietnam

\section{Introduction}

Vietnam is a country which has the advantage of exporting agricultural commodities and raw products to the world market. However, nowadays Vietnam does not really create its advantages for exports. The Vietnamese economy is still suffering from the negative impacts of market fluctuations. These fluctuations also have big effects on export activities of Vietnam.

Particularly, in recent years, the issues which are volatility of some strong currencies in the world and the Chinese government devalued their yuan have caused direct effect on the economy of Vietnam. Export - import operations are affected firstly. This causes significant impacts on the balance of trade in general and trade with partner countries in particular. Through this article, we analyze the fluctuations of yuan and Fed rates and their main effects on Vietnamese economy. We also focuse on the situation of the currency market in Vietnam and the actions of the State Bank of Vietnam (SBV) in helping to stabilize the domestic market.

Then, we look at the negative impacts of exchange rate fluctuations that affect the agricultural exports and the proposals for maintaining sustainability in agricultural exports to reduce market risks.

\section{Literature Reviews}

The exchange rate is an issue which researchers take often into account. The reason is any changes or adjustments in exchange rates have an impact on many aspects of the economy. In general, the Vietnamese economists often study the evolution of exchange rates in a certain period and the affects when the country integrates into the world economics. Besides, they also focused on the effects of exchange rate on export activities.

\subsection{Causes of Exchange Rate Policy's Ineffiency and Lessons for Vietnam}

Tran Phuc Nguyen and Duc Tho Nguyen (2010) have studied on exchange rate policy in Vietnam since Doi Moi 1986 to 2009. Having recognized the lack of effective operation of the Vietnam foreign exchange market, the authors explored the fundamental cause of the problem based on the micro approach and learned the negative impact of this inefficiency as: the lack of derivative instruments, low revenues, minor role in interbank transactions, the necessity of the State Bank on the market and liquidity risk. Besides, Nguyen Phuc Hien (2011) investigated the exchange rate in Vietnam by drawing China's experience. He found that the similarity of the current situation of the exchange rate in Vietnam to China in the late 1993. These are: high inflation and trade deficit due to the overvalued and low credibility rate, which is expected to put pressure on the VND's devaluation. Therefore, the author has analyzed policies which People's Bank of China applied to create advantages in promoting competitiveness and international productivity, increasing export activities and attracting foreign investors to pour their capital into the country. 
Nguyen Khac Minh, Pham Van Khanh and Nguyen Viet Hung (2015) not only assessed the impact of exchange rates but also analyzed the impact of FDI in Vietnam agriculture in the period 1998-2011. They have used flexibly models, which are the chance-constrained programming model and two-stage model, to exam the effectiveness of agricultural production under the impact of exchange rates and FDI. The estimated results show that fluctuation in exchange rate volatility would reduce efficiency in agricultural production but FDI has an insignificant impact on the efficient production in Vietnam agricultural sector.

Ronghua Ju, Ruihua Yang's study (2010) about the Chinese market which is affected by imported product flows from U.S. The paper established an empirical model to analyze the influence level of echange rate on the price of the land-intensive products imported from U.S. Whereby, the price of agicultural products is sensitive to the volatility of echange rate. If RMB increases, the RMB price of import goods in China will be relatively cheaper, make competitive pressure on domestic goods and that the export market becomes more difficult. This leads to decrease of export turn-over, finally reduce national income and jobs. Based on currently fluctuation in exchange rate, studying the lessons from China and the parallels between China and Vietnam help policy makers put forward effective policies in order to avoid negative impacts on domestic market.

Cláudia Maria Sonaglio (2016) shows that the real exchange rate is seen as one of the factors responsible for the reduction of the external competitiveness of Brazilian manufactures and this exchange rate valuation may be occurring due to the differences between domestic and international interest rates. The other paper of Dimitrios Serenis (2014) examines the effect of exchange rate volatility for a set of three African countries: Malawi, Morocco and South Africa to aggregate exports. The study has also suggested significant negative effects from volatility on exports for all the countries.

\subsection{Exchange rate in the Integration Period and the Impact on the Trade Balance}

Nguyen Thi Tuyet Nga (2012) focused on studying the role of the exchange rate for Vietnam's economy integration period. She has systematized the theory to further elucidate the basic theoretical issues on exchange rate and has researched experience from countries such as China, Thailand, Korea, Malaysia, and Mexico to learn lessons for Vietnam. To assess the role of the exchange rate integration period, the authors have studied the exchange rate's fluctuation in the period 1999-2011 and find problems in the current exchange rate. Thereby, the study also provided recommendations to adjust the exchange rate flexibly, maintain the equilibrium exchange rate stably based on the real purchasing power of VND through supply and demand relationship in the market; improve and stabilize the balance of payments, empower VND on international markets and control dollarization phenomenon. Pham Hong Phuoc (2009) has approached the problem about the exchange rate volatility impacting on the trade balance of Vietnam. The author focused on the determination of the multilateral real exchange rate or real effective exchange rate (REER) market in Vietnam in 1999 - 2008. Thereby, the study assessed the impact of REER on export-import operations in Vietnam by testing the regression model of the impacts of exchange rate on export-import ratio. Results showed that exchange rate has an impact on import-export activities, however, in addition to factors such as GDP which still played an important role on export-import activities.

Tran Nhuan Kien (2015) used gravity models to analyse the factors which affect the export of VietNamese agricultural goods. The paper shows that agricultural exports of Vietnam are under the influence of the fluctuations in global agricultural market since joining the WTO (2007). More specificially, this study indicates the fators which affect a country's export and import such as: exchange rate, population size, development gap among countries...Inside, exchange rate impacts in positive direction, every $1 \%$ increase in exchange rate makes exports of Vietnam average increase of 3,469\%. It means that the price of Vietnamese export products is affected by the price of US dollars. Therefore, stabilizing exchange rate is very important that the export of agricultural goods achieves sustained stable growth.

Phan Thanh Hoan (2007) applies cointegration theory and error correction model in order to verify impact of exchange rate both in the short term and in the long term on the balance of trade, thence construct model presenting their relationship. Result of the study shows the existence that relationship. In the short term, the impact of exchange rate is under the relative lag. However, in the long term they come to one balance relation. The influence of exchange rate on balance of trade is fast and strong, so if that we only base on the nominal exchange rate to analyze the effect of exchange rate on the balance of trade is incorrect. For this reason, he use actual exchange rates and mainly multilateral real exchange rate. Besides, Pham Thi Tuyet Trinh also use ECM model to determine the impact of real exchange rate on trade balance in short-run and long-run in Vietnam. The result of impulse response in model showed that there is a relationship between real exchange rate and trade balance of Vietnam. Author indicated that "a depreciation real 
exchange rate immediately causes significant negative impact on trade balance" in short-run and "real exchange rate does have positive impact on trade balance in the long-run".

Kristian Nilsson's research (2015) indicates why the exports of developing countries are subject to more severe consequences of exchange rate volatility than the exports of developed countries. First, in which exporters usually have little market power. Second, developing countries usually have underdeveloped finacial markets. In the fact that developing countries almost exclusively trade in US dollars, whereas almost developed countries, to some extent, trade in their domestic currency. Therefore, the exports of developing countries depend on the fluctuation of exchange rate strongly. The study also indicates that the more flexible exchange rate regime is, the greater the exports of developing countries.

Thus, in some extent, studies indicate relative impact of exchang rate on the exports of developing countries such as Vietnam. To export agicultural goods rise needs not only the agricultural supports but also stable policies of exchange rate by the development of domestic financial markets. However, most of them just stop the impact assessment not specific solutions to improve ability of the agricultural products export in general in the world.

Different studies have shown the negative impact of exchange rate on exporting agricultural goods of developing countries such as Vietnam. To increase in the value of export agricultural goods, in addition to the policies for supportin agriculture, Vietnam should stabilize exchange rate by the development of domestic financial markets. However, the studies just analyze the impact and there are no specific measures aimed at improving the ability to export agricultural products deeply.

\section{Exchange Rate in Vietnamese Economy}

Exchange rate is one of the important macroeconomic policies. The situation between US dollars and Euro, US dollars and JPY in the past period of time shows that exchange rate is always sensitively current issue. In Vietnam, the impact of exchange rate on not only exports and imports, balance of trade, public debt, FDI but also popular trust.

From 2014 to now, strong curencies in the world have had significant changes. In 2014, US dollars increase 14 percent and increase over 27 percent in period from 2014 to the middle of the second quarter in 2015 in comparison with different strong curencies such as: EUR, JPY, GBP, CAD, SEK and CHF.

Domestic situation in the first 4 months of 2015, after announcing adjusted scope of exchange rate is 2 percent for 2015, state bank of Vietnam increased interbank average exchange rate immediately up to 1 percent on January 7th, 2015. The adjusted activities are on the pressure of the demand of US dollars from companies and ceiling increasing of exchange rate on the interbank market. Then, exchange rate fell back that made condition for State bank of Vietnam to buy a large amount of foreign currency from the market to increase the reserve of foreign currency. However, in early march, 2015, exchange rate rise again because market psychhological afraid of the appreciation of US dollars on the international market. In addition, the trade balancede has been in deficit since December, 2015, which makes USD rising demand and that many banks increase buying USD in order to shut down the negative foreign currency to reduce exchange rate risk. So, the market to last April, 2015 exchanged at high price continuously and ceiling exchanged in a few days of the early may, 2015.

Therfore, in early 4 months of 2015, exchange rate fluctuation is continuously variable. It affects the trade balance of Vietnam strongly; base on that, the state bank of Vietnam offers timely solutions to reduce exchange rate risk.

In few recent months, exchange rate has affected continuously by countries with strong economics which have traded large export to another contries. State bank of China claims devalue RMB and FED is able to adjust interest rate in the end of 2015, they impact on many economies powerfully in the world.

\subsection{Impact of the RMB Devaluation}

The trade balance of Vietnam to May, 2015 was negative more 4 billion USD and higher much than the negative limit of the trade balance in the whole year of international organizations (for example: ANZ though that the negative level is limit of $0.5 \%$ GDP, equal to 1 billion USD in 2015). If the state bank of Vietnam do not adjust exchange rate, not only Vietnamese exports have disadvantage to compete with Chinese products and another export countries but also domestic consumer goods competes difficultly with import goods.

Especially, some major export products of Vietnam to China are affected strongly such as: agricultural products, raw material... Decreasing price of theirs (many products discount at lowest from 2009), in addition to the devaluatipn of RMB, the situation of agricultural exports with low profit margins meet with more difficulties. 
Besides, in some another field with advantage of exchange rate helps some Chinese organizations have many advantage of competiveness in bidding field of projects in infrastructure construction. Recently, it is the main driving force of the GDP growth.

Tourism sector which is already affected by recent events has difficulties continuously when tourists from China take highest percentage (in 2014, 25\% total of tourists from foreign coutries) and weakening of RMB. Therefore, they will prior to domestic tourism than foreign tourism. Group of FDI businesses are also affected heavily because they export a large quantity to China, especially electronics sector.

\subsection{Impact of the Fed's Interest Rate Adjustments}

That Federal Reserve (FED) decided to keep interest rate at 0\% at least to October, 2015 makes State bank of Vietnam adjust the interbank average exchange rate and loosen the ampitude of exchange rate $+/-2 \%$. This activity of state bank of Vietnam anticipates volatilities including devalue of Chinese currency and ability to adjusting interest rate of FED. Recently, leader of the state bank of Vietnam asserts not to adjust exchange rate and applies to solutions to stabilize exchange rate and foreign exchange market from now to early months of 2016.

Two impacts mentioned above that pressure of Vietnamese exports is improving quality of products and services, actively seeking new markets. In addition, claiming the whole populations consume domestic goods is necessary to guarantee for sustainable development of Vietnam economics on the context of the global market.

It shows that fluctuation of big economics impacts strongly on developing countries such as Vietnam and action of state bank of Vietnam is said to be necessary because it will support companies to export and improve the trade balance.

Base on the global market fluctuation, the role of Government and state bank of Vietnam is very important. Government regulation and intervention of state bank in exchange rate make balance of the international balance of payments, help national economy stable and avoid volatility outside.

The context of the economic market expanding, exchange rate policy continues to be operated like that; it impacts on investment in-out flows of Vietnam. There is no strong linkage with the foreign exchange markets; however, rapid price increase of USD on the global market recently has given rise to fears about competitive ability of Vietnam exports.

\section{Agricultural export of Vietnam}

\subsection{Exporting Agricultural Commodities in the First 9 Months of 2015}

In 2014, the balance of trade surplus has been $\$ 2.14$ billion for the first time since 2004 and exportation of 10 major commodities increased from 2013. For this reason, year 2015 is expected to promote the development of the previous year. However, in 2015, Vietnam has a difficult year with volatility of agricultural export market of Vietnam. In the first 6 months, the value of key export items dropped from the same period last year.

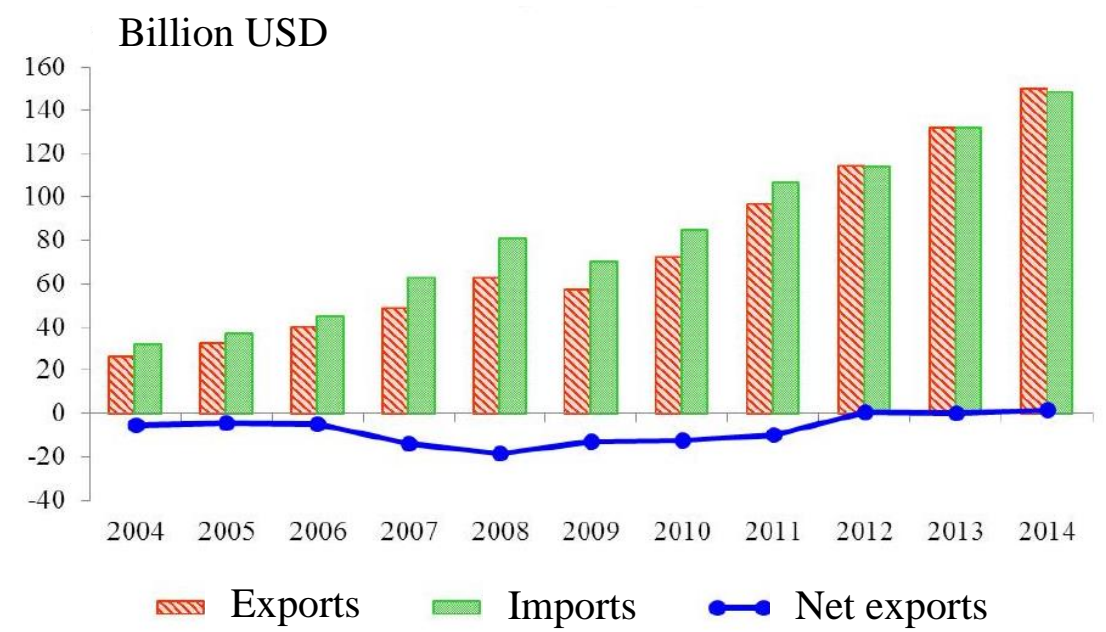

Figure 1. Exports, Imports and Net Exports in period 2004-2014

Source: General Department of Vietnam Customs 
The causes leading to the drop in the value of the exports of Vietnam include: (i) religious and political instability in many areas, which affects the overall needs of the world; (ii) the growth rate of agriculture in Vietnam has shown signs of slowdown compared with the average of the world; (iii) there are more intense competitions in the world market and (iv) nowadays, many importing countries want more control of imported commodities by increasing production capacity in their country and other protective policies. Besides these factors, variation in exchange rates due to the price adjustments of the strong currency aslo have big affects on exporting agricultural products of Vietnam.

\subsection{The Impact of Exchange Rate Fluctuations on Agricultural Exports of Vietnam}

\subsubsection{Exports}

According to data from the Ministry of Agriculture and Rural Development, exports of agriculture, forestry and fishery is estimated at $\$ 2.6$ billion in June 2015. The total exporting value in the first 6 months of 2015 is 14.42 billion, down $2.8 \%$ from the same period of 2014. In particular, the expoting value of major agricultural commodities is estimated at 6.93 billion dollars, down 5.7\%. For instant, a sharp decline in commodities such as rice (10.5\%), coffee (35.1\%) and seafood (16\% and the biggest drop in the US market with 29.07\%).

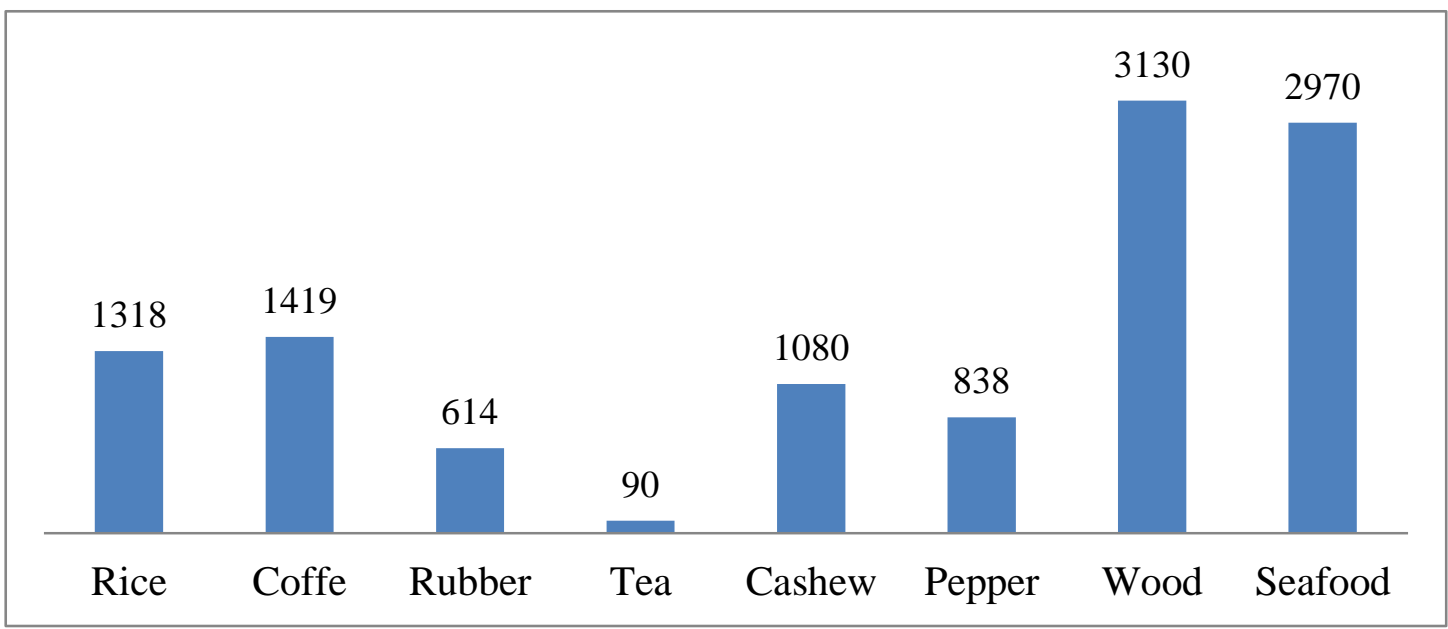

Figure 2. Exports of agricultural and forest commodities in the first 6 months of 2015

(million USD)

Source: Ministry of Agriculture and Rural Development

After 3 months of the third quarter, total agricultural exports in the first nine months of 2015 was estimated at over $\$ 10.3$ billion, down $7.2 \%$ from the same period in 2014; furniture and forest products reached 5.03 billion dollars, up $6.6 \%$; seafood reaching nearly $\$ 4.7$ billion, down $17.8 \%$. The total export value of agricultural and forest products in 9 months reached nearly 21.7 billion, down $5 \%$ compared to the same period last year. The whole industry's trade surplus reached $\$ 4.2$ billion, down $37.2 \%$.

\subsubsection{The Structure and the Competitiveness of Exports}

The agricultural products have very high elasticity. Therefore, these are sensitive goods with the fluctuations of the exchange rate than items of machinery, petroleum or completed equipments. Because, when the decrease in the exchange rate will make export products become expensive relatively. Foreign customers will tend to change their choice; especially in the context of strong competition from exporters around the world with high quality products. Besides, the increase in US dollar from the early 2015 makes importers create pressure on the price of these commodities. 


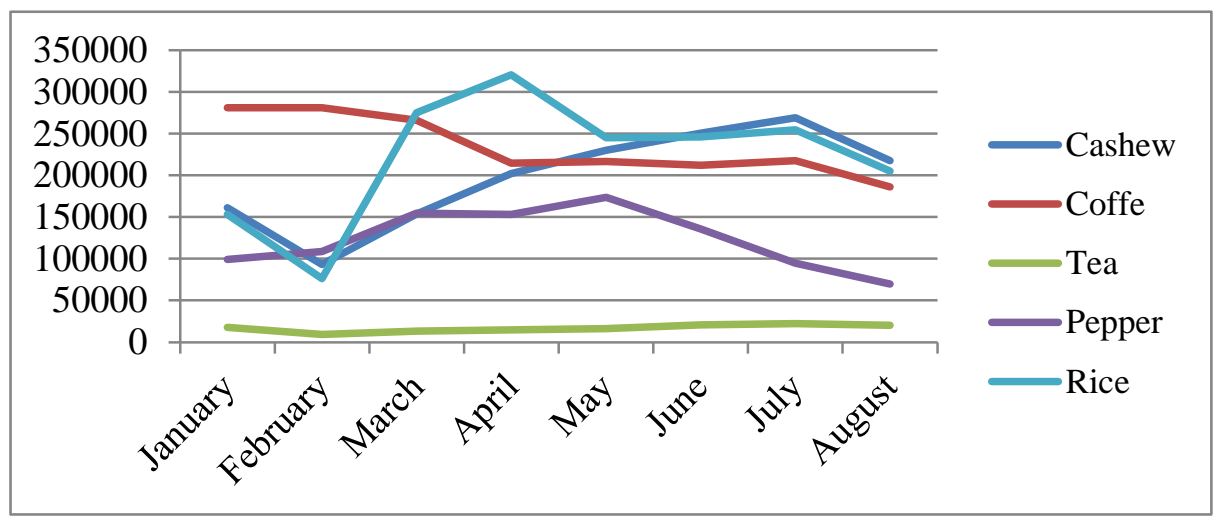

Figure 3. The export value of some agricultural products in the first 8 months of 2015

(million USD)

\section{Source: General Statistics Office of Vietnam}

According to figure 2, in February 2015 the export value of main agricultural products has declined compared to January. This was also the time when the exchange rate reduced and caused negatively impact on export. In March, State Bank of Vietnam adjusted exchange rate, which supported export. The fluctuation in exchange rate and fierce competitions in the trade easily lead to the risk of losing important segments of Vietnam. For example, competition from Brazil and Colombia in coffee export; Thailand in rice export. Especially, nowadays, Cambodia and Myanmar also reached out to foreign markets and the rice quality was also rated in high rank in the world.

\subsection{The lessons for Vietnam's Agricultural Sector}

Vietnam has an advantage in exporting a variety of important commodities in the world. However, the volatility of the market is easy to affect export performance in general and exports of agricultural products of Vietnam in particular. In 2015, the fluctuations in the exchange rate have affected foreign trade activities of Vietnam with customers around the world. The adjustment of the State Bank is a timely measure to reduce difficulties. However, this can only solve temporarily. We need long-term methods to overcome the negative effects in the future. Specifically for agricultural commodities we need to focus on these following points:

- In addition to focus on the key markets, Vietnam needs to look for opportunities in new export markets and take advantages of the participation of trade agreements such as the FTA, TPP to exploit new potential market.

- Enterprises should seek out information about export markets, the macro economy and the requirements of the product in advance to be more active in exporting agricultural products.

- Vietnam needs to improve the quality of agricultural products by following the world standards. Which is not only a quick way to export products to other countries but also make importers have confidence in Vietnam agricultural commodities. Besides, the high quality rise the value of export product and reduce the pressure to our production.

- Building Vietnamese brand and creating geographical indications for agricultural products of Vietnam. Strong pressure from other export countries is one reason why Vietnam needs to have the brand to make up the difference and use it as a key investment. A typical example like Cambodia has entered the rice export market since 2009. However, nowadays their products appear in 53 countries including more than half of exports to Europe. Production of Cambodia is a fifth of Vietnam's one but their value is very high. Especially, Phka Romdoul rice has been voted the world's best rice for five years.

- The link between the four factors - Government, scientists, entrepreneurs and farmers - should be attached special importance. Currently, there is still a huge gap between the four factors. In additon, building commodity value chain from production to consumption is still limited.

\section{Summary and Concluding Remarks}

As a result, the export market of Vietnam agricultural products does not take full advantage available of itselt and risk losing significant market share. The reason of this problem comes from many aspects, whereas exchange rate fluctuation among the national curencies impacts significantly. In some big export markets of Vietnam agricultural 
products, that exchange rate decline sharply makes the negative impacts on exports, so it makes the national trade balance deteriorate

To put forward solutions for Vietnam agricultural products is that not only intervention of Government and state bank in exchange rate policies but also improving quality of products and actively seeking the export markets are necessary and important.

This study only concentrates on analyzing general agricultural markets, further researches should be continued with specific agricultural products to find suitable solutions for every product. Because each product has its own characteristics, they will have different consumer markets and solutions to create efficient agricultural markets.

\section{References}

Cláudia Maria Sonaglio et al. (2016). Effects of interest and exchange rate policies on Brazilian exports. EconomiA. http://dx.doi.org/10.1016/j.econ.2016.01.002

Dimitrios Serenis, Nicholas Tsounis. (2014). Does Exchange Rate Variation Effect African Trade Flows? Procedia Economics and Finance, 14, 565-574. http://dx.doi.org/10.1016/S2212-5671(14)00757-6

Kristian Nilsson, Lars Nilsson. (2015). Exchange Rate Regimes and Export Performance of Developing Countries. The Quarterly Review of Economics and Finance.

Nguyen Khac Minh, Pham Van Khanh \& Nguyen Viet Hung. (2015). Impact of Exchange Rate Volatility and FDI on Technical Efficiency - A case study of Vietnamese Agricultural Sector. American Journal of Operations Research, 5, 317-325. http://dx.doi.org/10.4236/ajor.2015.54025

Nguyen Phuc Hien. (2011). China's exchange rate policy and international competitiveness (Export) 1994-2005: Is it a lesson for Vietnam. Economic Research Center Discussion Paper, No.183.

Nguyen Thi Tuyet Nga. (2012). The solutions for enhancing the role of exchange rates in the Vietnam economy's integration process, $\mathrm{PhD}$ Thesis of Banking University Hochiminh City.

Pham Hong Phuoc. (2009). Real exchange rate and the trade balance of Vietnam. Dissertation of University of Economics, Ho Chi Minh City.

Phan Thanh Hoan. (2007). The relationship between exchange rates and trade balances in Vietnam in the period 1995-2007. Science Journal, No. 43.

Pham Thi Tuyet Trinh. (2012). The impact of Exchange rate fluctuation on trade balance in short and longrun. Depocen Working Paper Series, No. 2012/23.

Ronghua Ju, Ruihua Yang. (2010). Risk of Exchange Rate Pass-through and Adaptive Strategies of Land-intensive Products in China: Taking Import Products from U.S. as an Example. Agriculture and Agricultural Science Procedia, Vol 1.

Tran Nhuan Kien. (2015). Factors affecting the exports of Vietnam. Journal of Economic Issues and World Politics, No 3.

Tran Phuc Nguyen \& Duc-Tho Nguyen. (2010). Vietnam's exchange rate policy and implications for its foreign exchange market, 1986-2009, Griffith Business School (AFE), Griffith University, Australia. 